\title{
Forum
}

\section{Carbon, forests and the REDD paradox}

\author{
Chris Sandbrook, Fred Nelson, William M. Adams and Arun Agrawal
}

\begin{abstract}
The institutional arrangements governing forests will be a critical factor in reducing emissions from deforestation and forest degradation (REDD) as part of the global effort to mitigate climate change. A growing body of empirical research demonstrates how local forest governance can be as, if not more, effective than centralized state-based regimes. Local forest governance can secure improvements in multiple forest outcomes such as biomass and carbon storage and livelihoods contributions for the poor, and it can do so at lower cost than is possible through centralized governance. Many national governments have implicitly recognized these findings in their pursuit of decentralized forest governance and in strengthening local rights and capacities to use and manage forests. However, such reforms are often politically resisted, particularly where the value of forest resources is high and central government bodies are able to capture the majority of benefits. Ongoing negotiations related to the design and delivery of REDD policy and practice must take into account both the importance of local forest governance arrangements and the political-economic barriers to devolving secure rights over forests to local communities. These political dimensions of forest tenure and policy create a paradox for REDD: increasing the value of forest resources through global carbon markets without attending to local governance and rights will create political incentives towards centralized governance, which could lead to greater forest loss and lower forest-related benefits for the poor.
\end{abstract}

Keywords Community, decentralization, global climate change, governance, payments for ecosystem services, REDD, tenure, tropical forest

\section{Introduction}

Torest loss, primarily tropical deforestation and forest - degradation, accounts for $12-17 \%$ of global greenhouse gas emissions (Rogner et al., 2007; van der Werf et al.,

Chris SAndbrook (Corresponding author) and William M. Adams Department of Geography, University of Cambridge, Cambridge, CB2 3EN, UK. E-mail cgsandbrook@gmail.com

Fred Nelson Fred Nelson Maliasili Initiatives Ltd, Arusha, Tanzania

Arun Agrawal School of Natural Resources and Environment, University of Michigan, Ann Arbor, Michigan, USA

Received 19 January 2010. Revision requested 10 March 2010.

Accepted 12 April 2010.
2009). Reducing emissions from deforestation and forest degradation (REDD) in developing countries has therefore become a priority for global climate change policy (IPCC, 2007; Stern, 2007). The most popular approach to REDD is a form of payments for ecosystem services that rewards reductions in forest loss and degradation (Bond et al., 2009). Payments for REDD will increase the economic value of forest resources in developing countries and the incentives for conserving forests. However, implementation of REDD projects faces a range of technical and institutional challenges (Angelsen, 2008). In particular, the design of any REDD mechanism must take account of existing knowledge about forest governance. This includes not only the effectiveness, efficiency and equity implications of different forest governance regimes but also the political processes that determine how forest governance institutions are shaped.

Here we review a growing body of empirical research that documents how local forest governance regimes can be as, if not more, effective than centralized state-based regimes in terms of achieving REDD and forest conservation outcomes under many different conditions. We review how political processes influence the shape of forest governance regimes in ways that are not related to technical forest management outcomes, particularly where the commercial value of forest resources is high. Finally, we introduce a resulting paradox for the delivery of REDD that increasing the value of forest resources through global carbon markets will create political incentives for governance arrangements that are unlikely to prevent forest loss and degradation.

\section{Governance, local communities and forest carbon}

Although scholars of macro-level deforestation trends have tended to focus on human population levels and market pressures as causal factors, increasing attention is now being paid, especially in studies of deforestation at the local level, to how forest governance institutions moderate such forces (Agrawal, 2007). Forest governance refers to 'who gets to decide what about forests, and how' (Cotula \& Mayers, 2009). The majority of the world's forests are owned by governments (86\%), with the remainder under private $(10 \%)$ or communal ownership $(<4 \%$; FAO, 2005). However, formal forest statistics under-report communal forest tenure. Furthermore, formal forest tenure regimes in developing nations are frequently characterized by a lack of transparency, high levels of corruption and weak 
enforcement. As a result, large areas of forest are effectively under complex informal tenure arrangements, distinct from customary tenure regimes (Bond et al., 2009; Cotula \& Mayers, 2009). In total, according to recently compiled figures, nearly $27 \%$ of all tropical forests are under various customary and communal tenure arrangements, and there has been an increasing trend towards decentralized forest governance in the tropics, where local communities and forest users now govern close to an additional 200 million ha of forests compared to the 1980s (Sunderlin et al., 2007; Agrawal et al., 2008).

A large body of theoretical and empirical research has examined the governance conditions conducive to sustainable management of communally held natural resources (Dietz et al., 2003; Ostrom \& Nagendra, 2006; Ostrom, 2009). This body of work highlights the importance of clear definition of user rights and responsibilities, participation by those who use and depend on forest resources, downward and horizontal accountability of decision makers and monitoring of forest management outcomes, stronger enforcement of property rights and governance arrangements, and high investments in institutional capacities locally, regionally and nationally (Agrawal et al., 2008; Ostrom, 2009).

Numerous national case studies of forest management across a diverse range of socio-economic and ecological conditions provide evidence of forest recoveries or conservation linked to relatively secure local rights to use and manage forests. Mexico provides a large-scale example of sustainable local forest management regimes, with as much as $80 \%$ of the country's total forest area under communal local ownership (Bray et al., 2003, 2005). Significant amounts of reforestation in Nepal's middle hills and Terai plains are attributed to the role of the country's communal forestry programme, with local forest regimes (either leasehold or communal) associated with forest recoveries whereas centralized government forests have continued to deteriorate (Nagendra, 2007). In Tanzania, which possesses one of sub-Saharan Africa's most advanced participatory forest management programmes, Blomley et al. (2008) synthesize data from a series of comparative analyses of locally managed or co-managed forests and open access or government-managed forests. They conclude that

All three of our case studies indicate that participatory forest management appears to be contributing to sustainable forest management ... This contrasts with measurements taken on land administered solely by government agencies with no community involvement, or on village land under open access arrangements, where forest condition is typically declining.

Additional important recent local or national case studies on the role of local collective forest governance regimes in preventing deforestation include studies from
India, Brazil and Madagascar. Somanathan et al. (2009) analyse remotely sensed data to conclude that for forests in the Central Himalayas, management by village councils 'costs an order of magnitude less per unit area, and does no worse, and possibly better at conservation than state management'. Nepstad et al. (2006) use remote sensing data to evaluate the impact of Brazilian indigenous community lands in preventing deforestation and fires along frontiers of land-use change and colonization and find that 'indigenous lands ... are currently the most important barrier to Amazon deforestation'. In Madagascar's tropical dry forests, Elmqvist et al. (2007) analyse changes in forest cover during 1984-2000 in four different locales. They find that the largest forest reduction in our surveyed area occurred in an area with distinctly insecure property rights and an open access situation', whereas a locale with recovering forest cover (Androy) was associated with effective local rules regulating forest use.

These and other local and national case studies highlight the importance of local rules and property rights in sustaining and recovering forests and are being complemented by more sophisticated comparative analyses across large numbers of forests in diverse settings. The International Forestry Resources and Institutions (IFRI) programme was initiated in 1992 and now includes data from 250 forests in 14 countries, using a variety of measures for forest condition, forest uses and institutional arrangements governing forests (Wollenberg et al., 2007). This growing database, built on a common set of 10 data collection instruments used for all studied cases, allows statistical analysis of variables associated with forest condition, and wider generalizations about links between people, forests and institutions than localized case studies. For example, Chhatre \& Agrawal (2008) analysed data collected from 152 forests in nine different countries and showed that forest degradation is inversely related to strong local collective action and enforcement of rules governing forest use. Hayes (2006) compared forest condition across 152 forests in 13 countries and found no significant difference in forest condition between formally protected areas and locally managed forests but highlighted the importance of locally devised rules in determining the condition of forests. Ostrom \& Nagendra (2006) used both IFRI studies and laboratory and field data to suggest that 'community management, under direct ownership, government concessions, or other long-term co-management arrangements, has the capacity to be as effective or, under certain conditions, more effective than public, strictly protected areas'.

This growing body of knowledge on forest governance is important in relation to efforts under REDD to invest in actions that reverse deforestation, which is often driven by weak forest governance and property rights arrangements (Cotula \& Mayers, 2009). Chhatre \& Agrawal (2009) extended the IFRI analysis of links between forest condition 
and governance regimes to explicit consideration of carbon sequestration, using data from 80 countries in Africa, Asia and Latin America. This analysis demonstrated that 'larger forest size and greater rule-making autonomy at the local level are associated with high carbon storage and livelihood benefits ... We argue that local communities restrict their consumption of forest products when they own forest commons, thereby increasing carbon storage'.

\section{The politics of forest governance reform}

Many of the case studies described above are drawn from countries where institutional reforms have taken place that grant local groups of people collective rights over forests. Such reforms have diverse origins, ranging from the communal land tenure reforms in Mexico, rooted in that country's early-2oth-century agrarian revolution, to Tanzania's village governance framework, which is rooted in the socialist development policies of the 1970s. Although there are a growing number of cases where local rights to make and enforce rules governing forests are associated with forest recoveries or sustainable use, it is also increasingly apparent that governance reforms involving devolved property rights to natural resources such as forests are often undermined by political resistance (Ribot et al., 2006). Strengthening local rights to manage and benefit from economically valuable natural resources such as forests can change power relations between local citizens and the state. Central governments may resist such changes, particularly where existing political relationships are undemocratic and public authority is maintained through various forms of social coercion. As a result, central governments tend to resist actual devolution of control over forests, even while often rhetorically espousing local participation (Ribot, 2006; Ribot et al., 2006; Tacconi, 2007). Forest governance reforms that support local management rights and authority are therefore not simply an issue of technical policy design but are closely tied to the politics of citizenship and accountability.

Forest governance reforms consequently involve struggles over access to benefits from natural resources. The outcomes of these processes depend on power relations both within and between local communities, powerful bodies within government, government organizations themselves and the private sector. Outcomes are affected by the freedom of local people to claim and defend their rights and privileges within an enforceable legal framework. Where local forest governance regimes have been enabled by institutional reforms it is often because local groups and their allies have been able to force changes within the context of broader social struggles over democracy. Examples of such reforms include the recognition of indigenous land and resource rights in Brazil, which were linked to social movements during the 1970s and 1980s, and the more recent Indian
Forest Rights Act of 2006 that was the product of campaigning by a diverse coalition of local tribal groups and civic activists for recognition of long-withheld indigenous rights (Springate-Baginski et al., 2008).

The economic value or 'rents' that can be derived from the exploitation of forest resources create strong incentives for central policymakers and governing elites to retain control over those resources and to subvert local rights and claims (Ribot, 2004; Roe et al., 2009). This may be particularly pronounced where the macro-political context is characterized by high levels of corruption, which means that public officials are able to capture and control resource rents privately (Oyono, 2004; Nelson \& Agrawal, 2008). Forest governance reforms that devolve authority may be more likely and more effective where the macro-political context is characterized by relatively stronger rule of law and governance institutions and where the resource in question is of relatively low value (Ribot, 2004; Nelson \& Agrawal, 2008).

\section{The REDD paradox}

Considering the evidence presented above it is clear that REDD schemes face a basic paradox. Revenues from REDD are intended to increase the value of standing forest. However, this will tend to increase the political incentives for central government bureaucracies to retain or re-centralize control over forests and the trade in carbon offsets. REDD payments are thus likely to create incentives for forest managers to return to past centralized models of forest conservation (Griffiths, 2007; Campbell et al., 2008) and potentially partner with private sector bodies in search for international financial support for enhanced carbon storage. Such governance arrangements have often been ineffective at sustaining forests, particularly where central states are weak (Campbell et al., 2008). REDD may therefore create political-economic incentives that undermine its operational objectives and theoretical principles.

In governance contexts characterized by weak rule of law and low levels of public accountability, REDD payments are likely to increase corruption and elite capture around forest governance institutions and forest product harvests. These processes will be particularly salient in regions such as the Congo Basin that have low levels of government accountability and weak rule of law compared even to other developing regions. In such contexts, REDD payments, without intensive efforts to create robust governance institutions and empower local forest users and resident communities, will probably have negative implications for forest condition and carbon emissions (Brown et al., 2008; Campbell et al., 2008; Peskett et al., 2008; Bond et al., 2009; Cotula \& Mayers, 2009) as well as for local livelihoods. Attempts to sustain forest cover through REDD may undermine decentralized governance associated with effective carbon storage (as well as provision of local livelihood benefits). 
Resolving this paradox rooted in the politics of REDD payments is a central challenge to effective global forest governance mechanisms that seek to meet climate change mitigation objectives. One approach is to make payments conditional on proven delivery of REDD, forcing government and private sector bodies to work with those capable of delivering effective stewardship over forest resources (Brown et al., 2008). However, this 'payment on delivery' approach could exclude small-scale bodies who lack the start-up capital needed to achieve REDD and reduce incentives for more 'pro-poor' REDD interventions (Peskett et al., 2008). An alternative approach would be to introduce forest governance criteria such as locally secured tenure rights and enforcement arrangements over land and trees that must be met before REDD payments are made (Griffiths, 2007; Wunder, 2008; Bond et al., 2009). These steps may increase the likelihood of success where appropriate conditions exist or can be introduced but would exclude substantial tracts of forest in high-deforestation countries with very poor governance conditions, thereby reducing the scope of REDD payments to contribute to climate change mitigation. These approaches should be complemented by providing global financial and technical support for improvements in forest governance institutions and incentives for local monitoring and reporting of REDD outcomes. Such key elements of REDD project design will lay stronger institutional foundations for REDD, thereby securing better forest governance as an additional product of lower terrestrial emissions. Such investments should focus on building the capacity of local communities to demand accountability in forest governance processes, third party forest monitoring, and support to civil society networks.

Tackling the causes of anthropogenic climate change is of overwhelming importance and requires urgent action. Introducing an international mechanism for REDD payments that recognizes the need for improvements in forest governance and addresses existing governance deficits in tropical forests has the potential to help achieve mitigation objectives and at the same time enhance forest conservation and improve livelihood benefits for poor forest residents.

\section{Acknowledgements}

The authors thank the late Ivan Bond and two anonymous reviewers for helpful comments on an earlier version of this article. We gratefully acknowledge the support to CS of the Economic and Social Research Council grant PTA-026-271787.

\section{References}

Agrawal, A. (2007) Forests, governance, and sustainability: common property theory and its contributions. International Journal of the Commons, 1, 111-136.
Agrawal, A., Chhatre, A. \& Hardin, R. (2008) Changing governance of the world's forests. Science, 320, 1460-1462.

Angelsen, A. (ed.) (2008) Moving Ahead with REDD: Issues, Options and Implications. Center for International Forestry Research, Bogor, Indonesia.

Blomley, T., Pfliegner, K., Isango, J., Zahabu, E., Ahrends, A. \& Burgess, N. (2008) Seeing the wood for the trees: towards an objective assessment of the impact of participatory forest management on forest condition in Tanzania. Oryx, 42, 380-391.

Bond, I., Grieg-Gran, M., Wertz-Kanounnikoff, S., Hazlewood, P., Wunder, S. \& Angelsen, A. (2009) Incentives to Sustain Forest Ecosystem Services: A Review and Lessons for REDD. International Institute for Environment and Development, London, UK.

Bray, D.B., Merino-Perez, L. \& Barry, D. (2005) The Community Forests of Mexico: Managing for Sustainable Landscapes. University of Texas Press, Austin, USA.

Bray, D.B., Merino-Perez, L., Negreros-Castillo, P., Segura - Warnholtz, G., Torres - Rojo, J.M. \& Vester, H.F.M. (2003) Mexico's community-managed forests as a global model for sustainable landscapes. Conservation Biology, 17, 672-677.

Brown, D., Seymour, F. \& Peskett, L. (2008) How do we achieve REDD co-benefits \& avoid doing harm? In Moving Ahead with REDD: Issues, Options and Implications (ed. A. Angelsen), pp. 107-118. CIFOR, Bogor, Indonesia.

Campbell, A., Clark, S., Coad, L., Miles, L., Bolt, K. \& Roe, D. (2008) Protecting the future: carbon, forests, protected areas and local livelihoods. Biodiversity, 9, 117-122.

Chhatre, A. \& Agrawal, A. (2008) Forest commons and local enforcement. Proceedings of the National Academy of Sciences of the USA, 105, 13286-13291.

Chhatre, A. \& Agrawal, A. (2009) Trade-offs and synergies between carbon storage and livelihood benefits from forest commons. Proceedings of the National Academy of Sciences of the USA, 106, 17667-17670.

Cotula, L. \& Mayers, J. (2009) Tenure in REDD-Start-Point or Afterthought? International Institute for Environment and Development, London, UK.

Dietz, T., Ostrom, E. \& Stern, P.C. (2003) The struggle to govern the commons. Science, 302, 1907-1912.

Elmquist, T., Pyykonen, M., Tengo, M., Rakotondrasoa, F., Rabakonandrianina, E. \& Radimilahy, C. (2007) Patterns of loss and regeneration of tropical dry forest in Madagascar: the social institutional context. PLoS One, 2, e402.

FAO (Food and Agriculture Organization) (2005) Global Forest Resources Assessment 2005: Progress Towards Sustainable Forest Management. FAO, Rome, Italy.

GrifFiths, T. (2007) Seeing 'REDD'? Forests, Climate Change Mitigation and the Rights of Indigenous Peoples and Local Communities. Forest Peoples Programme, Moreton-in-Marsh, UK.

Hayes, T.M. (2006) Parks, people, and forest protection: an institutional assessment of the effectiveness of protected areas. World Development, 34, 2064-2075.

iPCC (Intergovernmental Panel on Climate Change) (2007) Climate Change 2007: Climate Change Impacts, Adaptation and Vulnerability. Summary for Policymakers. Intergovernmental Panel on Climate Change, Geneva, Switzerland.

NAGENDRA, H. (2007) Drivers of reforestation in human-dominated forests. Proceedings of the National Academy of Sciences of the USA, 104, 15218-15223.

Nelson, F. \& Agrawal, A. (2008) Patronage or participation? Community-based natural resource management reform in subSaharan Africa. Development and Change, 39, 557-585. 
Nepstad, D., Schwartzman, S., Bamberger, B., Santilli, M., Ray, D., SChlesinger, P. et al. (2006) Inhibition of Amazon deforestation and fire by parks and indigenous lands. Conservation Biology, 20, 65-73.

Ostrom, E. (2009) A general framework for analysing sustainability of social-ecological systems. Science, 325, 419-422.

Ostrom, E. \& Nagendra, H. (2006) Insights on linking forests, trees, and people from the air, on the ground, and in the laboratory. Proceedings of the National Academy of Sciences of the USA, 103, 19224-19231.

Oyono, P.R. (2004) One step forward, two steps back? Paradoxes of natural resources management decentralization in Cameroon. Journal of Modern African Studies, 42, 91-111.

Peskett, L., Huberman, D., Bowen-Jones, E., Edwards, G. \& Brown, J. (2008) Making REDD Work for the Poor. Report prepared for the Poverty Environment Partnership, London, UK.

Riвот, J. (2004) Waiting for Democracy: The Politics of Choice in Natural Resource Decentralisation. World Resources Institute, Washington, DC, USA.

Riвот, J. (2006) Choose democracy: environmentalists' socio-political responsibility. Global Environmental Change, 16, 115-119.

Ribot, J., Agrawal, A. \& Larson, A. (2006) Recentralizing while decentralizing: how national governments reappropriate forest resources. World Development, 34, 1864-1886.

Roe, D., Nelson, F. \& Sandbrook, C. (2009) Community Management of Natural Resources in Africa: Impacts, Experiences and Future Directions. International Institute for Environment and Development, London, UK.

Rogner, H., Zou, D., Bradley, R., Crabbe, P., Edenhofer, O., Hare, B. et al. (2007) Introduction. In Climate Change 2007: Mitigation of Climate Change (eds B. Metz, O.R. Davidson, P.R. Bosch, R. Dave \& L.A. Meyer), pp. 95-116. Cambridge University Press, Cambridge, UK.

Somanathan, E., Prabhakar, R. \& Mehta, B.S. (2009) Decentralization for cost-effective conservation. Proceedings of the National Academy of Sciences of the USA, 106, 4143-4147.

Springate-Baginski, O., Sarin, M., Ghosh, S., Dasgupta, P., Bose, I., B Anerjee, A. et al. (2008) The Indian Forest Rights Act 2006: Commoning Enclosures? Conference paper presented at the 12th Biennial Global Conference of the International Association for the Study of the Commons, Cheltenham, UK. Http://
iasc2008.glos.ac.uk/conference\%2opapers/papers/S/SpringateBaginski_233001.pdf [accessed 2 September 2009].

Stern, N. (2007) The Economics of Climate Change: The Stern Review. Cambridge University Press, Cambridge, UK.

Sunderlin, W.D., Dewi, S. \& Puntodewo, A. (2007) Poverty and Forests: Multi-Country Analysis of Spatial Association and Proposed Policy Solutions. Center for International Forestry Research, Bogor, Indonesia.

TACCONi, L. (2007) Decentralization, forests, and livelihoods: theory and narrative. Global Environmental Change, 17, 338-348.

van der Werf, G.R., Morton, D.C., DeFries, R.S., Olivier, J.G.J., Kasibhatla, P.S., Jackson, R.B. et al. (2009) $\mathrm{CO}_{2}$ emissions from forest loss. Nature Geoscience, 2, 737-738.

Wollenberg, E., Merino, L., Agrawal, A. \& Ostrom, E. (2007) Fourteen years of monitoring community-managed forests: learning from IFRI's experience. International Forestry Review, 9, $670-684$.

W Under, S. (2008) Payments for environmental services and the poor: concepts and preliminary evidence. Environment and Development Economics, 13, 279-297.

\section{Biographical sketches}

Chris SANDBRook has research interests in conservation, development and tourism and has carried out both field research and applied project work in Uganda. He is currently working as a consultant for the International Institute for Environment and Development on community-based natural resource management and linkages between great ape conservation and poverty reduction in Africa, and on an applied collaborative forest management project in Vietnam. FRED NeLSON has worked on community-based natural resource management, ecotourism, and conservation policy in eastern Africa since 1998. During 2000-2005 he served as Tanzania programme director for the Sand County Foundation Community-Based Conservation Network, working with pastoralist communities in northern Tanzania and helping to establish the Tanzania Natural Resource Forum. BILL (William) Adams has a particular research interest in the history and development of conservation policy. ARUN Agrawal's work emphasizes the politics of institutional change and environmental governance, including adaptation to climate change. 